\title{
Television experience and political discussion on Twitter: exploring online conversations during the 2014 Brazilian presidential elections
}

\author{
Júnia Ortiz \\ Solange Hamrin \\ Camilo Aggio \\ Edson Dalmonte
}

\begin{abstract}
This empirical study aims to investigate the characteristics of the conversation and political discussion on Twitter during the last televised presidential debate in the first round of the Brazilian elections in 2014. Television experience, political participation, and Twitter dynamics were considered for the examination of different kinds of engagement in 100,000 messages collected during the debate. The aim was to identify peaks of user engagement, linking these specific moments and evaluating how the characteristics of the communicative environment may have affected the discourses built around the debate.
\end{abstract}

Keywords: Twitter; television experience; Brazilian presidential election; political discussion.

Resumo: Experiência televisiva e discussão política no Twitter: explorando conversações online durante as eleições presidenciais brasileiras de 2014 - Esta pesquisa empírica pretende investigar as características da conversação e da discussão política no Twitter durante o último debate presidencial televisionado no primeiro turno da eleições de 2014. A experiência televisiva, a participação política e a dinâmica do Twitter foram consideradas para o exame de diferentes tipos de engajamento em 100 mil mensagens coletadas durante o debate. O objetivo foi identificar picos de engajamento de uso, conectando esses momentos específicos e avaliando como as características do ambiente comunicacional podem ter afetado os discursos construídos ao redor do debate.

Palavras-chave: Twitter; experiência televisiva; eleição presidencial brasileira; discussão política. 


\section{Introduction}

Since the 1990s, both the media landscape and society have been transformed with drastic implications for the interpretations of audiences as a concept (CAREY \& ELTON, 2010; SULLIVAN, 2013). Several scholars emphasize that the digital era has contributed to the rise of the audience as an active agent, transforming users into producers, generating and disseminating news and other content through blogs and social networking sites (SNSs), independently of media organizations, and facilitators of participation and engagement in democratic dynamics (CAREY \& ELTON, 2010; NIELSEN, 2012).

Scholars are not unanimous, but despite doubts about the influence of a minority group with access to Internet and SNSs, this minority has been shown to be capable of forming pluralistic and varied networks (ANSTEAD \& O'LOUGHLIN, 2011) and influencing democratic views. They interact on Twitter with their knowledge, values, beliefs, and interpretations of facts in order to entertain and/or influence others (ANSTEAD \& O'LOUGHLIN, 2011). Furthermore, the 'viewertariat' (viewers who use online publishing platforms and social media to externalize their interpretations) can engage in activities to improve democratic principles through public discussion and, occasionally, deliberation. The use of Twitter essentially changes the nature of media consumption because it engages viewers in commenting on events and adding information to explain the broadcast (ANSTEAD \& O'LOUGHLIN, 2011).

In the following sections, we examine the contribution of Twitter to political engagement and a brief overview of conversation patterns on Twitter. We then present the hypotheses, methodology, results, and conclusions of the study, analyzing comments on Twitter about the most important televised electoral debate in 2014 Brazilian presidential election.

\section{Twitter and Users' Political Engagement}

Despite being viewed with great skepticism, social media are known to give a favorable perspective to citizens as active agents in democratic processes (COLEMAN \& BLUMLER, 2012; LARSSON \& MOE, 2011), transforming audiences into independent producers and disseminators of content. The idea behind the concept of 'engagement' applied in this paper refers to how SNS users take advantage of the opportunities provided by SNSs to share information and content, publish original messages, and discuss with other users in order to accomplish a myriad of social and political purposes from discussing messages from public officials, pundits, or social organizations to conversing about content such as televised debates or TV series. In addition to political attitudes, political information consumption and political participation are also part of the political engagement (JENSEN \& JORBA, 2012).

'Political participation' is an even more popular term in discussions of social media and democratic processes and refers to users being part of the political process through 
voicing their own opinions, often as an action to influence the outcome of a political issue (GIL DE ZUNIGA, JUNG, VALENZUELA, 2012). In contrast, 'engagement' includes active participation, increased interest, and contribution to the process in question.

Those opposing the claim that the Internet can enhance citizen participation and engagement, state that the Internet does not provide an instrument enabling deliberations and that the engagement is individual rather than collective (COLEMAN \& BLUMLER, 2012).

Social media have a remarkable ability to forecast electoral results and a noteworthy correlation is found between SNSs and poll results (CERON, CURINI, IACUS, \& PORRO, 2014). However, studies suggest that social media use has a small impact on participation (BOULIANNE, 2015) and that politicians have not learned to take advantage of the interactional nature of social media, fail to interact with citizens, and insist on using one-way communication that does not bridge the gap between the elite and citizens $(\mathrm{HOSCH}$ DAYCAN, AMRIT, AARTS, \& DASSEN, 2014). Both the media and political parties are more active online than citizens. Citizen participation is classified as negative or persuasive, depending on the type of participation in SNSs. Negative messages are shared more frequently and can also be interpreted as acts of expression (HOSCH-DAYCAN et al., 2014; AGGIO, 2014). However, social media are assumed to advantage citizens and the democratic process because they facilitate the participation of 'old audiences', granting them greater access to government, and attendance of public speeches which might increase opportunities for collective action (SHIRKY, 2011). In addition, social media attract a completely new order of participants to the political discourse and promote the professionalization of campaigns by influencing prevalent media logics (HOSCH-DAYCAN et al., 2014).

Twitter has been studied as it enables the discussion of controversial topics, affecting other media logics and, consequently, agendas. Twitter does not compete with television. Instead, the 'second screen' phenomenon reinforces the interrelation between these two media. Giglietto and Selva (2014) confirmed the coexistence of different and interlinked forms of participation during peaks of Twitter activity during broadcasts. They analyzed approximately 2.5 million tweets collected over a season of 11 political talk shows and revealed a relationship between scenes in political talk shows, the style of the comments, and the type of participation (audience and political).

Although television is still central, SNSs, and especially Twitter, contribute to innovation because of the possibility of including other agents' voices. Citizens can express their interpretations of content in real time and influence the selective broadcasting process. Audiences have the capacity to share and discuss their views with non-specified imagined audiences or even television producers in real time during the broadcast. Whether frequent or sporadic users, viewers strive to achieve different goals: to interpret, to comment on, and to discuss various elements with other users during the broadcast (GIGLIETTO \& SELVA, 2014). 
The viewertariat is an outcome of the blending of old and new processes to form new systems and practices. One of the contributions of SNSs is that they can bolster mobilization by engaging with viewer responses and adding new information to annotate the broadcast; the use of Twitter suggests a substantive change in the nature of media consumption (ANSTEAD \& O'LOUGHLIN, 2011). It has characteristics that enhance interactions of the public or different sectors of the public across media platforms. Anstead and O'Loughlin (2011), in a case study of a BBC Question Time episode from October 2009 where Nick Griffin (leader of the controversial British National Party) appeared, investigated how one high profile broadcast triggered real-time commentary from viewers on Twitter. The researchers analyzed the interactions on Twitter, the network frames, and how Twitter users argued about the episode. Discourse analysis was also used to understand attributions of social identities among the 'viewertariat', exploring how individuals understand their relationship with the group and the activity they are engaged in. The authors concluded that the forms of engagement triggered by Griffin's appearance on Question Time are likely to be a recurring element of political communication in Britain as in other parts of the world. Their findings also indicated how changing audience practices can generate dynamics that pull otherwise distanced individuals into a mainstream political event. In this case, Twitter somehow added value to television as a medium, and to its language, in addition to the hard discussion about its functionality. Similar results were found by Trilling (2015) analyzing 120,557 tweets during a televised debate in the German election campaign of 2013, where the candidates barely managed to take the discussion of main topics to Twitter and the discourse on Twitter was sarcastic or humoristic.

Another study about live-tweeting during political debates has found that citizens' deliberations were not a feature of social media dialogue in live-tweeting (HAWTHORNE, HOUSTON, \& MCKINNEY, 2013). In addition, the findings showed very few differences between tweets of the media, political elites, and public sources, although the views of elites spread further than those of non-elite users at times.

Considering the convergence perspective (JENKINS, FORD \& GREEN, 2013) marked by a participatory culture and a new flux of multilinear communication in opposition to the traditional one, television can be viewed with new expectations. Reflecting on its cultural/ historical centrality from the second half of the $20^{\text {th }}$ century to now, two main perspectives emerge: firstly, instead of simple consumption, the television experience is the result of a connection among various media, mixing languages and circulating on different platforms and gadgets, i.e., a spreadable media (JENKINS et al., 2013); secondly, and probably more importantly, citizenship can be expanded if considered across the current media stage as a result of a 'television experience.'

If television is technically closed on itself as much as newspapers are (STRÖMB̈̈CK, 2008), it cannot contribute to public participation in political debates since it cannot allow such conversations around it. However, at the current stage of experiencing television 
through Twitter, the scenario has changed and the detection of changes is the main objective of this article.

\section{Conversation Patterns}

Patterns and trends are formed on Twitter depending on the followership, the presence and participation of individual and group networks during debates. D'heer and Verdegem (2014) investigated the relationships among the media, political actors, and citizens, analyzing patterns on Twitter during the Belgian election period. They suggested that one's presence in the conversation network is unrelated to one's position in the media or in the political field; thus, citizens are present as much as other agents. Furthermore, their findings indicated little interaction between different agents in the networks, where one agent was usually connected to just one other agent and the networks were dispersed. A priori, the distribution of comments on Twitter is unequal among commentators since entry often happens only once. This may indicate that users do not follow up on ideas and comments for or against their own opinions, problematizing the notion that what they do on Twitter is a debate, discussion, or even a dialogue (ISAACS, 1999). Anstead and O'Loughlin (2011) revealed that $20 \%$ of those commenting on a TV program on Twitter were responsible for more than $50 \%$ of the content.

Maireder and Schlögl (2014) reconstructed the dynamics of a debate about sexism in Germany, examining the hashtag \#aufschrei (\#outcry) to visualize networked publics, mapping the diffusion of the conversation and the emergent discourses. The discourse was first developed and shared by a homogeneous cluster that later created varied discourses over a number of hours. Initial tweets of personal experiences evolved into broader debates about the topic by the 'Pirate cluster' (Pirate Party affiliates and their followers). Regardless of size, the clusters were able to spread the discourses to other communities. The authors did not see significant changes in participation related to media reports on the discourses. However, blog posts written by certain representatives of the 'feminism cluster' led to other members writing other blog posts including quotes from the Twitter discussion, contributing to diversity in the debate.

In Brazil, some studies present similar scenarios, but focusing on how social movements and agents - previously lacking visibility and voice in the public sphere now use SNSs to: (a) engage in creating alternative narratives to public events framed or not by the traditional media (ANTOUN \& MALINI, 2012); (b) demand information and discuss with public officials and electoral candidates (AGGIO, 2014), and (c) share their experiences of cultural goods with other users (MALINI, 2014).

There is also a concern on how to analyze the consumption of television content synchronized to SNSs. To this purpose, Ortiz and Dalmonte (2015) suggested a framework considering the complexities of online conversations and the social environment. 
Based on the Brazilian context, the authors proposed some elements for the study of messages published on SNSs about television content. Among the suggested variables, we highlighted message function analysis, which would allow understanding of the main purpose of a publication, and thematic analysis, which would account for the content addressed by the published messages. For Ortiz and Dalmonte (2015), due to the amount of data in this type of analysis, the study of the content generated in SNSs must start from the recognition of the variables and categories relevant to the proposed research, to enable data systematization in order to make the investigation feasible.

\section{Hypotheses}

The theoretical discussion presented above indicates that SNSs can and actually do facilitate political participation in the form of comments and discussion over public events. The same is true for social interactions concerning the consumption of cultural/ media goods, such as TV series, political news, etc.

In order to assess how SNSs are used as communication platforms to experience public and media events in a given national reality, as well as how they can foster public participation, we have analyzed Twitter use by Brazilian viewers during a televised political debate based on the understanding that television provides context for political discussion in the online environment and, at the same time, that the conversations can modify the construction of meaning regarding the televised content.

This analysis aimed to investigate the characteristics of the conversation and political discussion on Twitter during the debate, considering the television experience, social and political conversation, and Twitter dynamics, and to evaluate how the communicative environment affected the discourses around the debate as a product.

Two hypotheses guided this work:

- $\quad H 1$ : In line with previous findings, the political issues addressed by the candidates will not motivate a significant number of messages on Twitter. This behavior can be explained by the fact that broadcast political debates, as media events, offers themes and opportunities for comments and conversation that extrapolate the boundaries of traditional political issues.

- H2: At times of a greater volume of comments, most will demonstrate audience engagement rather than political engagement. Given that broadcast debates are much more than mere political events (see $\mathrm{H} 1$ ), an increase in tweets in a given period of time will be related to extraordinary behaviors by candidates or journalists as perceived by the audience. 


\section{Method}

The data came from the conversations on Twitter during the last televised debate before the first round of the presidential elections in Brazil, aired on October $2^{\text {nd }}, 2014$, by Globo TV and considered to be the most important debate among seven candidates from parties represented in the House of Deputies. Each candidate met and debated with one another in rotation. In each 'Confrontation', the candidates had the right to direct a question to the opponent. The televised debate consisted of 4 blocks with a total of 134 minutes and 42 seconds. The candidates chose the discussion topics in the first and third blocks. While in the second and fourth, the topics were given to the candidates.

\section{Data Collection}

Using the DiscoverText software, we collected 100,000 messages during the first hour of the broadcast (the first and second blocks) using the following keywords: the candidates' names and possible variations (Neves, Rousseff, Jorge, Fidelix, Genro, Silva, Everaldo); the words 'debate' and 'Globo'; the official hashtags created by the candidates (\#Marina40, \#EuVotoMarina40, \#Aécio45, \#45AécioConfirma, \#Dilma13, \#Dilma13MudaMais); others created by users (\#CalaBocaLevy, \#LucianaNaGlobo); and general hashtags about the debate (\#DebateNaGlobo, \#G1, \#Eleições2014). Although we used the DiscoverText Gnip integration, which allowed us to collect a larger amount of data than the free Search API, samples were operationally limited to a maximum storage of 100,000 data units. Due to the format similarity of the first and third and second and fourth blocks, the limitation in the number of tweets did not generate implications for the results here presented.

\section{Data analysis}

In order to understand the standard of conversation on Twitter about the political content broadcast in a televised debate, we evaluated the type of user engagement political or audience - as defined by Giglietto and Selva (2014). To better understand the type of engagement, we explored the content and function of the messages (ORTIZ \& DALMONTE, 2015) that also revealed how the communicative environment may have affected the discourses around the debate as a product. A contingency analysis (OSGOOD, 2009; BARDIN, 2010; KRIPPENDORFF, 2004) of the tweets used three main variables: (a) topic, (b) message function, and (c) type of engagement. To explore these variables, we analyzed the data as follows.

a. Topic. The categories or topics were generated with this thematic categorical analysis (AGGIO, 2014; AUSSERHOFER \& MAIREDER, 2013; ARAGÓN et al. 2013; AHARONY, 2012). Six main topics emerged from the raw data. We then 
verified the frequency of the messages and labeled each message by the topic which the user referred to, namely: campaign for posts created by the official campaign profiles or showing support for a candidate; performance, referring to the specific behavior of a candidate in the debate; clash, about a confrontation between two candidates; situation, discussing issues related to the Brazilian social-political-economic context; debate, about the debate in general; and other, any messages that did not fit any of the other categories.

b. Message function. To identify the function of the message in the context of the debate it is essential to the understanding of the nature of user engagement. We used variables suggested by Ortiz and Dalmonte (2015) built specifically to analyze message function in a context of consumption of television content synchronized to social network sites (ORTIZ \& DALMONTE, 2015): opinion, expressing an assessment, opinion, or value judgment; information, informative messages from official organizations, blogs, specialized websites, or any user of the network; action/check-in (so-called by platforms specifically aimed at audiovisual content sharing), revealing an action at that very moment (we were interested in explicit reports that the user was watching the television product); satire, messages with irony or jokes; quote, words taken directly from somebody's speech; rhetorical questioning, addressing someone, an organization, or even a subjective character, as a discursive effect, not intended to obtain information or a response; and interjection, expressing a "state of mind" or emotion.

c. Type of engagement. Our assessment was inspired by the study where Giglietto and Selva (2014) classified messages into two categories: audience participation and political participation. For the purposes of this study, we replaced 'participation' with 'engagement' because it more clearly reflects what we are focusing on in relation to audience or political engagement. Thus, although we considered that every tweet had political content as a backdrop, audience engagement referred to messages that commented on the televisual structures, the debate within the television production logic, and observations on performance, technical errors, and confrontations as true frames in a series. Political engagement was observed when the message showed political motivation in itself and used the debate as a springboard to confirm political beliefs - which were mostly explanations about the way the tweeter thought s/he might vote and opinions regarding a candidate and/or her/his positions on a certain topic discussed in the debate.

\section{Results}

In order to understand the dialogical dimension of these messages, we took into account the use of the interaction tools offered by Twitter. Public messages can be sent as: original 
tweets (140-character message written by a user without using interaction tools and available in the timeline of any person who follows that user); replies (addressing someone directly); retweets or RTs (copies of messages from other users); and mentions (of usernames).

Of the total collected tweets, $56.7 \%(n=56,721)$ had mentions, of which $91 \%$ $(n=51,565)$ were RTs. Thus, only 5,156 were pure mentions, in that they used the feature to question, answer, or just name another user in the message body. This means that only $5.1 \%$ of the messages had dialogical potential.

An observation of the users mentioned can help us better understand these numbers. The most mentioned users were: @dilmabr with 5,609 entries and @jeanwyllys_real with 3,360. The incumbent candidate, Dilma Rousseff, owns the profile @ dilmabr. All messages mentioning @dilmabr were mentions or replies, as no comments from that account had been posted during our monitoring. On the other hand, messages mentioning @jeanwyllys_real, used by Congressman Jean Wyllys, were mostly RTs.

Several studies have built typologies in order to identify and classify the roles of participants in online discussions. Golder (2003), for instance, identified seven different types of individuals: newbie, celebrity, elder, lurker, flamer, troll, and ranter. Specifically, about Twitter, Zhao et al. (2013) considered two broad user categories in a conversation: originators, who publish original tweets, and propagators, who retweet and spread messages.

Although our goal was not to conduct a thorough analysis of the social role of Twitter users who commented on the presidential debate, the terms cited above give us clues as to how to think about the profiles mentioned. The large volume of references to @ dilmabr can be easily explained by the fact that Rousseff was running for re-election, making her the center of attention, simultaneously an object of communication, an interlocutor, and an issue. In contrast, Jean Wyllys was an originator and facilitator of the flow.

To test $\mathrm{H} 1$, we averaged tweets based on postings per second and identified the upper outliers through the statistical calculation of the median and quartiles. We thus found nine moments when the number of messages per second was abnormally high, creating a conversational flow greater than the average during the first hour of the debate, with a total of 1,098 tweets constituting the sample for this study.

We then performed a content analysis to understand which events these messages were related to. As seen in Table 1, most of the messages were satirical or comments on the performances of the candidates or the moderator. The most notable episode was when Fidelix chose Genro for a confrontation. In the previous debate, aired by Record TV four days earlier, Fidelix had made what was considered a strong statement against same-sex marriage, which caused extensive negative responses on SNSs. This time, calling Genro to the centre, Fidelix stated authoritatively: "Come here. Come here. I'm going to put you on the spot"1 . Along with his controversial statements, his manner itself was odd and exaggerated, which triggered satirical comments, several followed by memes and/or hashtags as \#CalaBocaLevy (\#ShutUpLevy).

1 Authors' (free) translation to English. The original sentence: "Vem aqui. Vem aqui. Vou te enquadrar." 
During peaks, comments were not necessarily connected to the political issues being discussed, rather, most of them were satirical comments on the performance of the candidates, on the reaction of the studio audience, or on the moderator's performance. This confirms our first hypothesis.

\begin{tabular}{|c|c|c|c|c|c|c|c|c|c|}
\hline \multicolumn{9}{|c|}{ Message function } \\
\hline Topic & Quote & $\begin{array}{c}\text { Action } \\
\text { check-in }\end{array}$ & Informative & Interjection & $\begin{array}{c}\text { Rhetorical } \\
\text { questioning }\end{array}$ & Opinion & Satirical & Other & TOTAL \\
\hline Campaign & 2 & 0 & 10 & 4 & 3 & 15 & 6 & 0 & 40 \\
\hline Performance & 19 & 0 & 25 & 19 & 52 & 122 & 388 & 0 & 625 \\
\hline Debate & 0 & 4 & 10 & 5 & 7 & 10 & 133 & 0 & 169 \\
\hline Clash & 13 & 0 & 10 & 7 & 4 & 59 & 120 & 0 & 213 \\
\hline $\begin{array}{c}\text { Current } \\
\text { situation }\end{array}$ & 0 & 0 & 0 & 0 & 1 & 2 & 1 & 0 & 4 \\
\hline Other & 3 & 0 & 8 & 3 & 6 & 4 & 22 & 1 & 47 \\
\hline TOTAL & 37 & 4 & 63 & 38 & 73 & 212 & 670 & 1 & 1098 \\
\hline
\end{tabular}

Table 1. Cross-tabulation between topic and message function $(n=1,098)$

As expected, users appeared to be more engaged in the television experience, with $65.4 \%$ of the messages categorized as showing audience engagement, as opposed to $36.6 \%$ showing political engagement, which confirms $\mathrm{H} 2$. A variable that proved to be important in determining the engagement type of a message was the candidate's position in the electoral race. In general, comments about the candidates with the highest polling numbers (Rousseff, Neves, and Silva) demonstrated political engagement $(71.9 \%)$. In contrast, most of the messages related to minority candidates (Everaldo, Genro, Jorge, and Fidelix) demonstrated audience engagement (72.4\%). Among comments that did not refer to any candidate, $89.6 \%$ showed audience engagement (see Table 2 ).

\begin{tabular}{|c|c|c|c|c|c|}
\hline & & & \multicolumn{2}{|c|}{ Type of engagement } & \multirow[b]{2}{*}{ TOTAL } \\
\hline & & & $\begin{array}{c}\text { Political } \\
\text { Engagement }\end{array}$ & $\begin{array}{c}\text { Audience } \\
\text { Engagement }\end{array}$ & \\
\hline \multirow{8}{*}{ Candidate } & \multirow{2}{*}{ Majority } & Count & 133 & 52 & 185 \\
\hline & & $\%$ within candidate & $71.9 \%$ & $28.1 \%$ & $100.0 \%$ \\
\hline & \multirow{2}{*}{ Minority } & Count & 111 & 291 & 402 \\
\hline & & $\%$ within candidate & $27.6 \%$ & $72.4 \%$ & $100.0 \%$ \\
\hline & \multirow{2}{*}{ Majority vs. minority } & Count & 96 & 29 & 125 \\
\hline & & $\%$ within candidate & $76.8 \%$ & $23.2 \%$ & $100.0 \%$ \\
\hline & \multirow{2}{*}{ No candidate } & Count & 40 & 346 & 386 \\
\hline & & $\%$ within candidate & $10.4 \%$ & $89.6 \%$ & $100.0 \%$ \\
\hline & \multirow{2}{*}{ TOTAL } & Count & 380 & 718 & 1098 \\
\hline & & $\%$ within candidate & $34.6 \%$ & $65.4 \%$ & $100.0 \%$ \\
\hline
\end{tabular}

Table 2. Cross tabulation between candidate's position and type of engagement $(n=1,098)$ 
The large number of candidates may have generated a certain pattern among users, who seemed to alternate between times when it was important to pay attention to the issues being discussed, and times when it was possible to relax and have fun with situations not related to political themes during the debate. The so-called 'minority candidates' had on average $1 \%$ of the votes according to polls and their government plans and positioning on political issues appeared not to attract Twitter users' attention or be worth tweeting about, although the statements of minority candidates were important for scenery and the political discussion as a whole.

\section{Discussion and Conclusions}

Previous studies on Twitter user participation and social media comments during TV events indicated that there is an increased participation, yet no strong engagement in political issues on Twitter (HAWTHORNE, HOUSTON \& MCKINNEY, 2013; ANSTEAD \& O'LOUGHLIN, 2011). Studies also emphasized that actors' influence is more equal on social media with the exception of comments from a celebrity (D'HEER \& VERDEGEM, 2014). There is little or no one-to-one interaction between actors (MAIREDER \& SCHLÖGL, 2014) and no dialogue (ISAACS, 1999) happening in these networks (ANSTEAD, O'LOUGHLIN, 2011).

The use of Twitter for comments and discussion during televised debates requires further investigation to fully comprehend its nuances. However, as far as the theoretical framework suggested here is concerned, the present study generally confirms previous research. The Twitter flow indicated that most people tweeting during the first and second blocks of the debate were not commenting on political issues but exchanging jokes about some extraordinary occurrence between candidates during the debate. Similar results were obtained by Trilling (2015) on what German Twitter users published while watching a televised debate between candidates for chancellor in 2013. As a public space, Twitter served as an arena where Brazilians were more interested in making fun of or commenting on the performances of the candidates and the moderator rather than in posting information or engaging in discussions. As Trilling (2015) pointed out, an optimistic view suggests that Twitter can serve as a "complement to draw attention to topics neglected in the official

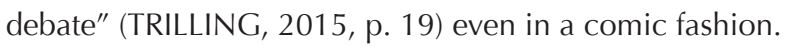

Considering Twitter's potential for bringing people together for debates, our findings show that Brazilian users did not use the interactive features (mentions and retweets) to interact directly with other users in order to discuss political issues (MAIREDER \& SCHLÖGL, 2014) but mostly to replicate and endorse someone else's comment rather than to engage in direct dialogical interaction with other users.

Our findings indicate how important opinion leaders are on Twitter as well (D'HEER \& VERDEGEM, 2014). Congressman Wyllys, one of the most active Brazilian politicians on Twitter and other SNSs at the time, was the most mentioned profile after President Rousseff. The large and consistent network of followers Wyllys had built, along with 
his active presence commenting on social and political events on a daily basis, helps to explain why he collected a significant number of endorsements translated as retweets. The fact that Rousseff's account was the most mentioned during the first hour of the debate demonstrates, once more, that Twitter is not a forum for social and political discussion during a televised debate, but a channel for people to make unidirectional comments and to reproduce and endorse other users' or leaders' viewpoints.

We found that the candidates' position in the electoral polls determined the type of engagement of Twitter debate commentators. Political engagement was more prevalent in tweets mentioning majority candidates while most of the messages related to minority candidates demonstrated audience engagement. Of those comments that did not refer to any candidate, $89.6 \%$ showed audience engagement as well. This distribution demonstrates that people's behavior on Twitter was not detached from the social and political reality. The media and public agenda still played an important role in influencing some part of the engagement process.

With this paper, we hope to contribute to cross-national research on public opinion, SNSs, and political engagement through a Brazilian case study. Specifically, we hope the data as well as its analysis will shed light on how Twitter serves as a platform for social commentary and discussion on televised debates as well as how our findings could be useful in explaining how the process works in different countries.

Edson Dalmonte is $\mathrm{PhD}$ and associate professor, Department of Communication at Federal University of Bahia (UFBA).

edsondalmonte@gmail.com

Camilo Aggio is $\mathrm{PhD}$ and assistant professor of Communication Theories, Department of Communication at Federal University of Minas Gerais (UFMG).

camiloaggio@gmail.com

Júnia Ortiz is $\mathrm{PhD}$ and Postdoctoral Researcher at Federal University of Bahia (PósCom/UFBA); she is a former Fulbright Visiting Researcher in the Comparative Media Studies Program at MIT (2014-2015).

junia.ortiz@gmail.com

Solange Hamrin is $\mathrm{PhD}$ and assistant professor at Department of Media and Communication Science at the Mid Sweden University.

solangehamrin@gmail.com 


\section{References}

AGGIO, C. Campanhas políticas e sites para redes sociais: um estudo sobre o uso do Twitter na eleição presidencial brasileira de 2010. 247 f. Tese de doutorado - Programa de Pós-Graduação em Comunicação e Cultura Contemporâneas. Universidade Federal da Bahia, Salvador, 2014.

AHARONY, N. Twitter use by three political leaders: an explanatory analysis. Online Information Review. 36(4), 2012, p. 587-603.

ANSTEAD, N.; O'LOUGHLIN, B. The emerging viewertariat and BBC question time: Television debate and real-time commenting online. The International Journal of Press/Politics, v. 16, n. 4, pp. 440-462, 2011.

ANTOUN, H.; MALINI, F. Monitoramento, vazamentos e anonimato nas revoluções democráticas das redes sociais da internet. Revista Fronteiras (Online), v. 14, pp. 68-76, 2012.

ARAGÓN, P.; KAPPLER, K. E.; KALTENBRUNNER, A.; LANIADO, D.; VOLKOVICH, Y. Communication Dynamics in Twitter During Political Campaigns: The Case of the 2011 Spanish National Election. Policy and Internet. 5(2), 2013, pp. 183-206.

AUSSERHOFER, J.; MAIREDER, A. National Politics on Twitter. Information, Communication \& Society. 16(3), 2013, pp. 291-314.

BARDIN, L. Análise de conteúdo.(1977). Lisboa (Portugal): Edições, v. 70, 2010.

BOULIANNE, S. Social media use and participation: A meta-analysis of current research. Information, Communication \& Society, v. 18, n. 5, p. 524-538, 2015.

CAREY, J.; ELTON, M. CJ. When media are new: understanding the dynamics of new media adoption and use. University of Michigan Press, 2010.

CERON, A. et al. Every tweet counts? How sentiment analysis of social media can improve our knowledge of citizens' political preferences with an application to Italy and France. New Media \& Society, v. 16, n. 2, p. 340-358, 2014.

COLEMAN, S.; BLUMLER, J. G. The Internet and Citizenship: Democratic Opportunity or More of the Same? In: H. A. Semetko \& M. Scammell (Eds.), The SAGE handbook of political communication, p. 141, 2012.

D'HEER, E.; VERDEGEM, P. Conversations about the elections on Twitter: Towards a structural understanding of Twitter's relation with the political and the media field. European Journal of Communication, v. 29, n. 6, pp. 720-734, 2014.

FOLHA DE SÃO PAULO. (2015/05/18). Bonner pede desculpas após dizer que americano tem 'cara de maluco' no 'JN'. Disponível em:<http://f5.folha.uol.com.br/televisao/2015/05/1630779-bonner-pededesculpas-apos-dizer-que-americano-tem-cara-de-maluco-no-jn.shtml>. Acesso em: 28-03-2017.

GIGLIETTO, F.; SELVA, D. Second screen and participation: A content analysis on a full season dataset of tweets. Journal of Communication, v. 64, n. 2, p. 260-277, 2014.

GOLDER, S. A. A typology of social roles in usenet. 73 f. Harvard University, 2003. Disponível em: <http://ibrarian.net/navon/paper/A_Typology_of_Social_Roles_in_Usenet_A_thesis_sub. pdf? paperid=1667977>. Acesso em: 28-03-2017.

HAWTHORNE, J.; HOUSTON, J. B.; MCKINNEY, M. S. Live-tweeting a presidential primary debate: exploring new political conversations. Social Science Computer Review, v. 31, n. 5, pp. 552-562, 2013.

HOSCH-DAYICAN, B. et al. How do online citizens persuade fellow voters? Using Twitter during the 2012 Dutch parliamentary election campaign. Social Science Computer Review, v. 34, n. 2, pp. 135-152, 2016. 
ISAACS, W. Dialogue and the art of thinking together: a pioneering approach to communicating in business and in life. New York, NY: Currency, 1999.

JENSEN, M. J.; \& JORBA, L. Digital media and political engagement worldwide: a comparative study. Cambridge University Press, 2012.

JENKINS, H.; FORD, S.; GREEN, J. Spreadable media: creating value and meaning in a networked culture. NYU press, 2013.

KRIPPENDORFF, K. Content analysis: an introduction to its methodology. Sage, 2004.

LARSSON, A. O.; MOE, H. Studying political microblogging: Twitter users in the 2010 Swedish election campaign. New Media \& Society, v. 14, n. 5, pp. 729-747, 2012.

MAIREDER, A.; SCHLÖGL, S. 24 hours of an \#outcry: The networked publics of a socio-political debate. European Journal of Communication, v. 29, n. 6, pp. 687-702, 2014.

MALINI, F. Literatura, Twitter e Facebook: a economia dos likes e do RTS dos usuários-fãs de literatura brasileira nas redes sociais. Revista Observatório Itaú Cultural, v. 17, pp. 204-233, 2014.

NIELSEN, R. K. How newspapers began to blog: Recognizing the role of technologists in old media organizations' development of new media technologies. Information, Communication \& Society, v. 15, n. 6, pp. 959-978, 2012.

ORTIZ, J.; DALMONTE, E. F. Construindo uma proposta metodológica para pensar as relações entre TV e Sites de Redes Sociais. In: RIBEIRO, J. C.; BRAGA, V.; SOUSA, P. V. (Org.). Performances interacionais e mediações sociotécnicas. 1ed.Salvador: EDUFBA, 2015, v. 1, pp. 187-208.

OSGOOD, C. E. Contingency Analysis: validating Evidence and Process. The Content Analysis Reader. Los Angeles: Sage, 2009.

SHIRKY, C. The political power of social media: Technology, the public sphere, and political change. Foreign Affairs, pp. 28-41, 2011.

STRÖMBÄCK, J. Four phases of mediatization: An analysis of the mediatization of politics. The International Journal of Press/Politics, v. 13, n. 3, pp. 228-246, 2008.

SULLIVAN, J. L. Media audiences: effects, users, institutions, and power. Sage Publications, 2012.

TRILLING, D. Two different debates? Investigating the relationship between a political debate on TV and simultaneous comments on Twitter. Social Science Computer Review, v. 33, n. 3, pp. 259-276, 2015.

ZHAO, X. W. et al. Originator or propagator?: Incorporating social role theory into topic models for twitter content analysis. In: Proceedings of the 22nd ACM international conference on information \& knowledge management. ACM, 2013. pp. 1649-1654. 